\title{
Childcare for Sale: Mapping Private Institutions in Sweden 1900-1975
}

Johanna Sjöberg and Johanna Sköld

The self-archived postprint version of this journal article is available at Linköping University Institutional Repository (DiVA):

http://urn.kb.se/resolve?urn=urn:nbn:se:liu:diva-173333

N.B.: When citing this work, cite the original publication.

Sjöberg, J., Sköld, J., (2021), Childcare for Sale: Mapping Private Institutions in Sweden 1900-1975, Journal of the History of Childhood and Youth, 14(1), 113-132. https://doi.org/10.1353/hcy.2021.0013

Original publication available at:

https://doi.org/10.1353/hcy.2021.0013

Copyright: Johns Hopkins University Press

http://www.press.jhu.edu/journals/ 


\section{Childcare for Sale: Mapping Private Institutions in Sweden 1900-1975}

Johanna Sjöberg and Johanna Sköld

\section{Abstract}

Private providers and commercial profit are features of today's Swedish welfare society, but the market was already an arena for the production, distribution and consumption of such services by the early twentieth century. One of the private-sector institutions offering well-to-do parents residential care for their children during restricted periods was the so called Barnpensionat (Eng.: Children's boarding house). Since these institutions are not previously studied, the extent and organization of such establishmentss are unknown. Through analyses of digitalized newspaper material, including advertisements, this article maps the existence and function of barnpensionat in Sweden during the period 1900-1975.

\section{Introduction}

Private providers and commercial profit are features of today's Swedish welfare society, especially within the residential care sector for children and adolescents, in which 75 percent of the units are run by for-profit providers. ${ }^{1}$ But the market was already an arena for the production, distribution, and consumption of out-of-home care services by the early twentieth century. The historical significance of profit within welfare is not well known in Sweden, whose welfare state's universalistic principles have proven strongly symbolic. Children in particular have been perceived as a collective responsibility, and a uniform childhood for all children has been understood as an important product of the welfare state. The general development of the Swedish welfare state has been described as a process of both decommodification - citizens have become less dependent on the market to achieve a good standard of living-and defamilization - the extent to which the welfare state has made care-dependent individuals less reliant on relatives. ${ }^{2}$ But this typology has focused on the social rights of adult citizens, not those of children. In effect, children growing up in private-sector care, including care provided for profit, have been rendered invisible in welfare-state theory.

One kind of private enterprise, known in Sweden as barnpensionat (children's boarding houses or child hotels), arose during the 1910s. These were primarily private-sector institutions offering parents residential care for their children for a restricted period of time. However, these 
particular institutions have never been subjected to any major scientific investigation. The reasons for this might be that the barnpensionat was a marginal phenomenon compared to the massive expansion of public child-welfare institutions during the twentieth century and that these private services have left few traces in the public archives. This means that the function, clientele, and organization of institutions labelled barnpensionat have yet to be explored.

In this article, barnpensionat are studied through analyses of digitalized newspaper material, including advertisements, to map the existence and function of these institutions in Sweden and how this changed during the period 1900-1975. The following questions are scrutinized:

- How many barnpensionat operated in Sweden? When and where were they most frequent?

- What services and facilities were offered by such institutions?

- Who ran them?

\section{Previous Research}

During the past decade, research on the welfare state in Sweden has shown a new interest in welfare markets, such as the market for residential care for children and the market for early childhood education. However, these contemporary studies have often failed to address the historical dimensions of such welfare markets, with only a few exceptions. ${ }^{3}$ Moreover, previous historical research into child welfare has regularly ignored for-profit care providers (a notable exception is Shurlee Swain's article on the adoption market), ${ }^{4}$ while directing their main research interests toward philanthropic, religious, and public institutions for children. ${ }^{5}$ This imbalance means that we know more about institutions for working-class children than we do about those for the privileged. Another effect is that parent-child separation has typically been characterized and theorized as an intervention by the state or by philanthropists in order to "rescue" children rather than as an active parental choice. 
Identifying previous research about barnpensionat or related institutions has presented major obstacles. First of all, we have struggled with how to label institutions categorized as barnpensionat when writing about them in English. "Children's boarding house" is one of several possible translations. However, as similar institutions may have existed elsewhere but might have been labeled differently, we decided not to make any translation in order to avoid connotations that might not be accurate. In Denmark, the concept of the child hotel (Da.: børnehotel) has been applied. To our knowledge, no research has addressed these child hotels in Denmark, but a Danish museum exhibition described them as private institutions that took in children while their parents went on holiday, were sick, and so on. However, they were also places to which children who were perceived as "difficult to handle" were sent. ${ }^{6}$ In Sweden, two student essays have addressed barnpensionat and reveal similar functions. The essays demonstrate that these institutions seem to have functioned as recreational sites for children who were perceived as being in need of fresh air and a visit to the countryside, but also as a childcare solution for wealthy parents vacationing without their children. ${ }^{7}$ Consequently, barnpensionat could be perceived as one of the various types of childcare institutions operating between the public and private sectors that proliferated during the twentieth century, such as kindergartens, nurseries, and child-minding (Sw.: barnparkering) ${ }^{8}$ But unlike many such childcare facilities, most barnpensionat offered residential care around the clock, and many of the enrolled children were separated from their parents and families for days or weeks, sometimes even months, as this article will demonstrate. In this respect, barnpensionat in Sweden have parallels with what in other contexts have been conceptualized as holiday homes, convalescent homes, or summer camps. ${ }^{9}$ In her thesis about Scottish convalescent homes, Jenny Cronin found that after the First World War, such homes for children became increasingly associated with vacationing, and their previous distinct medical function for the sick and poor became blurred with "those in need of a country or seaside holiday." 10 In effect, these 
convalescent homes subsequently also attracted clientele from the middle class and became something other than charitable institutions. Another kind of institution that might resonate with the barnpensionat are summer camps (Sw.: koloni). These camps hosted many children in large buildings in the countryside for several weeks during the summer. They were managed by hired staff and provided organized activities. In Sweden, such institutions were established during the 1880 s by philanthropic societies aiming to safeguard the health and education of the children of the urban poor. In parallel with these summer camps, a system of boarding out children to rural families during the summer was also in place. Until the 1970s, admissions to the summer camps prioritized children from working-class families who were considered to be in need of fresh air, decent food, and proper childcare during the summer holidays when schools were closed. It was not until the 1990s that summer camps became a recreation site for middle-class children as well. ${ }^{11}$ However, some upper-secondary schools established their own kind of summer camps for middle- and upper-class children. Joakim Landahl, who studied one such camp for male pupils that existed during the period 1938-1965, concludes that their purpose was to inculcate autonomy in future leaders by creating a miniature society at the camp. ${ }^{12}$ Similarly, the purpose of fostering autonomy in children has also been identified in France by Laura Lee Downs. Summer camps, or colonies de vacances as they were labeled in French, have been sites for spiritual formation, the political indoctrination of working-class children, and - most importantly — a tool for educating the autonomous and independent democratic citizen. Downs maintains that parent-child separations in France were a popular practice and hence challenges the idea that such separations were always an intervention by child-rescuers who acted to "rescue" children from poor home environments. In essence, the function of the colonies de vacances could be interpreted as an aspect of defamilization, which, in a Scandinavian context, addresses a significant characteristic of the welfare state: making caredependent individuals (children) less reliant on relatives (parents). Downs maintains that 
parent-child separations in Britain have been narrated differently-as something that is damaging for the child. ${ }^{13}$

It should be underlined that not only children, but also many adults, vacationed away from home during the summer. Throughout the better part of the twentieth century, the market for guesthouses and boarding facilities run by private entrepreneurs was considerable, and the barnpensionat must be situated within this context. Approximately two thousand guesthouses or boarding facilities were identified in Sweden in 1931, and twenty years later this number had increased slightly. ${ }^{14}$ The passing of the first Swedish paid holiday act in 1938, entitling each employee to a two-week vacation, was important for the normalization of holiday trips. Bluecollar workers, however, did not reside in the same locations as white-collar workers. Guesthouses had, by tradition, a distinctly middle-class appearance. ${ }^{15}$

While many of the childcare institutions, camps, and boarding-out organizations were subsequently taken over by municipalities and became integrated into public welfare, institutions labelled barnpensionat seem to have vanished when the modern welfare state expanded. As such, they represent a category of for-profit institutions that did not achieve the transition to the public sector, which makes a study of them an investigation into the anomalies of the developing welfare state.

\section{Data and Method}

When searching for data to approach this little-known phenomenon, we quickly realized that no archives would hold any extensive material from private entrepreneurs running barnpensionat. However, a few official government reports (Sw.:SOU) published during the $1930 \mathrm{~s}$, '40s, and '50s have mentioned them. ${ }^{16}$ To gain some insight into the reasons barnpensionat services were hired by parents, we have analyzed surveys collected for one of these official government reports. As the reports only provide a snapshot of how many of these institutions there were and what function they were said to have in a given year, a longitudinal 
picture of the existence of barnpensionat requires other data. Therefore, we have collected advertisements and news items about barnpensionat in the Swedish newspapers available from the Swedish National Library's database Svenska dagstidningar (Eng: Swedish newspapers). This database today covers about 700 different scanned and digitalized newspaper titles published between 1645 and 2019. ${ }^{17}$ Similar databases are now available in various national contexts and the search facilities within digitalized media offer opportunities for historians to conduct research that was previously very time-consuming. Moreover, it facilitates new ways to find data about private businesses that have not supplied data to public archives. Shurlee Swain explored such data when she used an Australian digitalized newspaper database in her mapping of the adoption market through advertisements in Australia during the period 1850 1950. ${ }^{18}$ Her study shows that the material from such a database gives a solid indication of what was going on in that market.

While digitalized newspaper databases offer historians new opportunities to conduct research, there are novel pitfalls as well. The database Svenska dagstidningar is not complete; it is a continuously ongoing project to scan and digitalize old newspapers. ${ }^{19}$ This means that the results of any search in this database are very time specific, and this instability requires some important source-critical remarks that we shall revisit in the following sections.

We searched the database in September 2018 for the term "barnpensionat" and received 1,576 hits. ${ }^{20}$ These hits are distributed between 1899 and 2017. The concept of "barnpensionat" was unusual before 1915, and it was most frequent during the 1940s (236 hits), 1950s (428 hits), and 1960s (293 hits). The concept disappeared in the late 1970s. Thereafter, it was mentioned a few times in obituaries and only returned to any great extent in the 1990s when a radio program addressed the history of barnpensionat, using the personal experience of the journalist editing the program as a point of departure. This program was first broadcast in 1993, and rebroadcast in 1997, 2001, and 2016. 
In order to focus on the time when the barnpensionat was a historical reality rather than something being looked back at, we have focused on the hits during the period 1915-1977, a total of 1,437 . These hits cover a great variety of texts, from advertisements to short news items and full-length articles.

\section{How Many, When and Where?}

Addressing the question of how many barnpensionat have existed in Sweden required us to register all the different establishments that were mentioned in the advertisements, news items and articles. In total, we identified 165 different establishments, 160 located in Sweden and five abroad. Of these, 122 were identified through their own promotional advertisements in newspapers. The remaining forty-three were mentioned in news items and in advertisements to, for example, hire staff.

Should we consider 160 barnpensionat throughout Sweden to be many or few? Well, in relation to public institutions for children, this number is quite low. The city archive of Stockholm lists 132 children's homes operating in the Stockholm area only during the nineteenth and twentieth centuries. ${ }^{21}$ This indicates that the 160 barnpensionat all over Sweden represent quite a marginal phenomenon. But it is important to emphasize that the figure is just a minimum. As the database does not yet cover all local newspapers, it is likely that we have missed several. Furthermore, it is possible that some establishments did not advertise their services or were never mentioned in the media, which means that we will not have identified them through our mapping.

On the other hand, the number of barnpensionat could be exaggerated in our register due to factors such as the same institutions being labeled differently at different times. This is a risk particularly during the earlier period, when branding by using a clear trademark or company name was not applied in this type of market. Of 122 advertisers in our data, forty-seven did not promote a name at all, or at least not a clear name, to label their service. Moreover, some had 
similar names, which makes them difficult to distinguish from each other. For example, the common real-estate name "Solberga" was the name of one barnpensionat on the west coast and of a different one on the east coast. We have also observed that the same entrepreneur could operate in several different locations. Sometimes they moved to another place and took the old name with them. Conversely, the name of a barnpensionat could remain the same after a change of ownership. All in all, this has complicated our registration.

We have tried to define services that were offered in the same building, and by the same entrepreneur, as one establishment. If the entrepreneur then launched another service, at another location, this has been defined as an additional establishment. But if a barnpensionat was passed on to another entrepreneur while the company name remained the same, we have not differentiated between the two and this place has been registered as one barnpensionat only.

When were barnpensionat most common? To address this question, we have studied how many individual establishments were advertising in the newspapers each year. Because some advertised one year, not the next, but then again during the third year, we have presumed that they were active during the period between their first advertisement and their last. From this compilation, we can estimate how many barnpensionat were active at the same time. The results are presented in Figure 1. 


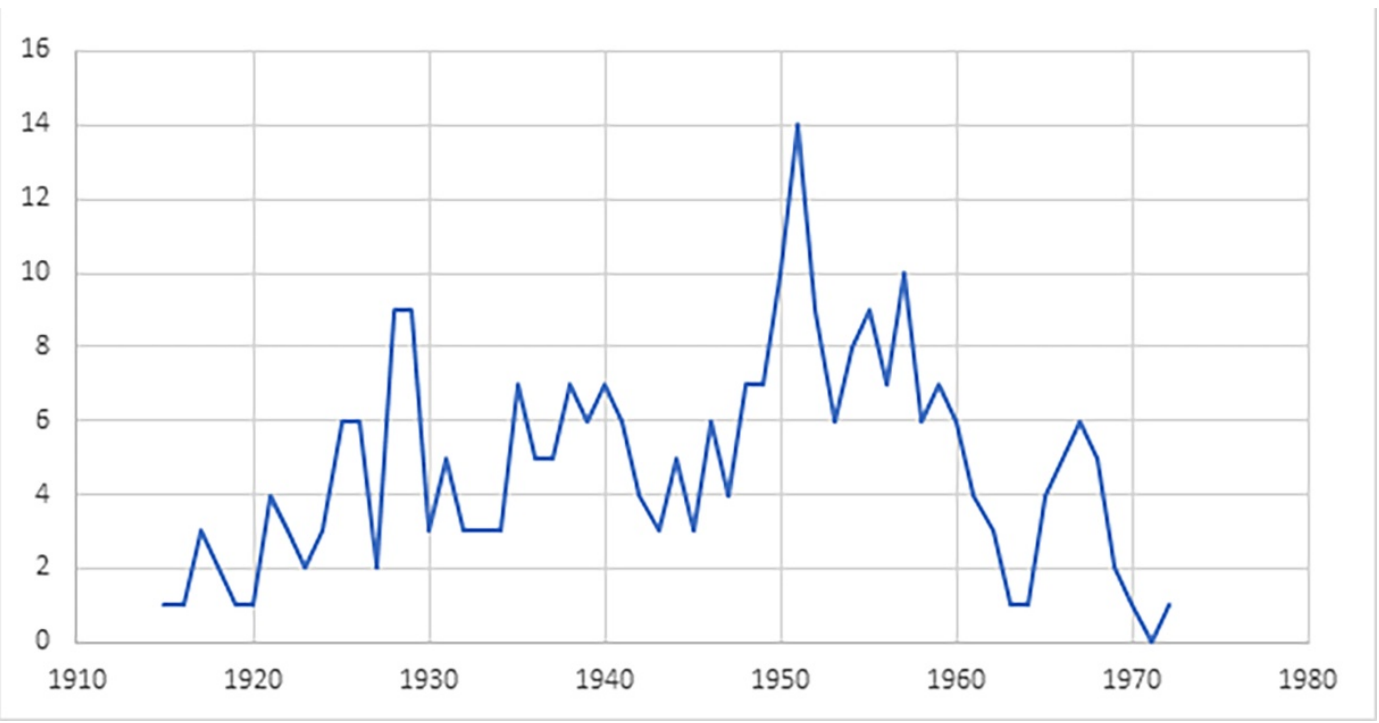

Figure 1. The minimum number of barnpensionat active at the same time.

Figure 1 shows that the number of active barnpensionat fluctuated over the years, with a peak in 1951, when at least fourteen different institutions were operating at the same time. Another interesting peak is 1928-1929, when nine barnpensionat were active in each of the two years. During the latter period, the number of active establishments varied considerably from year to year, from one in 1964 to six in 1967 and back to zero in 1971, with the last active barnpensionat that we have been able to identify through advertisements operating in 1972 . Again, these results must be interpreted with caution. Some individual barnpensionat might have advertised over several years with occasional interruptions, and some continued to be active but did not advertise once their name had become well-known. Hence, Figure 1 should be read as representing the minimum number of active barnpensionat each year.

The first to enter the market by promoting its service through advertisement was Syster Majas barnpensionat (Eng: "Nurse Maja's barnpensionat"). This actor was a frequent advertiser, and through the recurring advertisements we can conclude that the service was active from 1915 until at least 1932. Unlike Syster Majas barnpensionat, many barnpensionat popped up for just a short period of time. The number of new advertisers appearing each decade is another way to map the market; see Table 1. 


\begin{tabular}{|c|c|}
\hline PERIOD & NEW ACTORS \\
ADVERTISING \\
\hline $\mathbf{1 9 1 0}-1919$ & 4 \\
$\mathbf{1 9 2 0}-1929$ & 26 \\
$\mathbf{1 9 3 0}-1939$ & 22 \\
$\mathbf{1 9 4 0}-1949$ & 18 \\
$\mathbf{1 9 5 0}-1959$ & 38 \\
$\mathbf{1 9 6 0}-1969$ & 13 \\
$\mathbf{1 9 7 0}-1979$ & 1 \\
\hline
\end{tabular}

Table 1. New actors advertising each decade

In the early period, during the 1910 s, four individual barnpensionat were advertising. The interwar period saw a rapid expansion, with twenty-six new services entering the market during the 1920s and twenty-two during the 1930s. A peak can be identified in 1928, with eight new actors advertising in the newspapers that year. In comparison, the same number of new actors entered the market during the entire Second World War period in the 1940s. After the war, a new expansion period was set into motion. The 1950s stands out, with thirty-eight new actors advertising in the papers. In 1951 alone, ten new barnpensionat started to advertise. The final period, the 1960s and early 1970s, saw a rapid decline in first-time advertisements for barnpensionat-only fourteen new advertisers entered the market during this two-decade period. In conclusion, our mapping of advertisements shows that the heyday of barnpensionat prevailed between the mid-1920s and the end of the 1950s.

\section{Geographic Location}

Figure 2 shows a map of Sweden and where the barnpensionat in our data were located. It shows that most of them were close to Stockholm, the capital and largest city in Sweden. 
Notably, quite a few were also located close to the mountains in the north, perhaps because skiing and hiking became popular tourist activities from the 1930s onward. The few barnpensionat in the remaining northern parts of Sweden partly reflect the fact that these areas were not as densely populated as southern Sweden. But that does not explain why we have identified so few establishments in the very south and southeastern parts of the country. Rather, this may reflect the incompleteness of the database. When controlling the Svenska dagstidningar for local newspapers in the southeastern and southern parts of Sweden, we discovered that several influential newspapers have not yet been digitalized, ${ }^{22}$ which possibly made our results geographically biased. By mapping out the geographical locations of barnpensionat, we were also, to some extent, mapping the coverage of the database. This is an important source-critical aspect of using digitalized historical media-it is important to understand that there are limitations to databases.

However, most barnpensionat in our data were not identified through local press, but in the large Stockholm-centered papers, regardless of their own geographic location. There are even examples of barnpensionat that offered child transportation from Stockholm to the institutions, located in completely different parts of the country. ${ }^{23}$ This demonstrates the importance of Stockholm parents as a target group for barnpensionat services, and it shows that children might have had to travel long distances to get to the chosen establishment. 


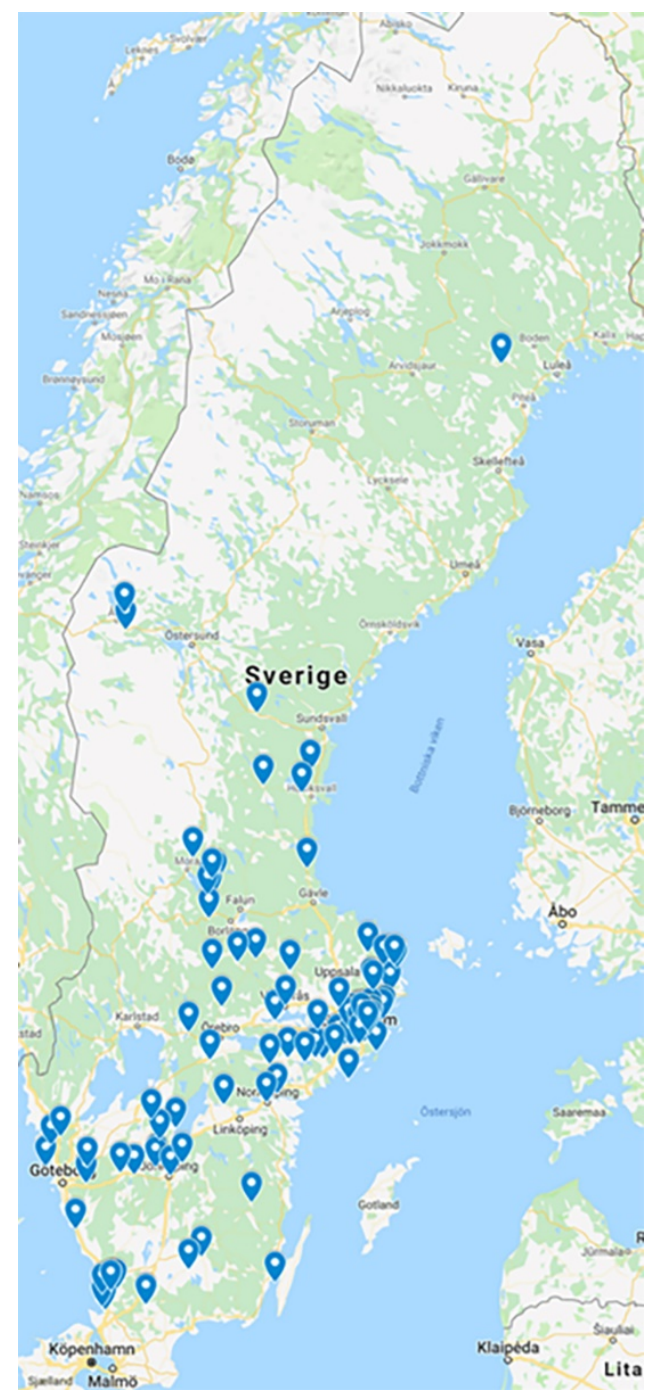

Figure 2. The geographic location of barnpensionat, 1915-1975. The map was generated by using Google Maps, https://www.google.com/maps.

Swedish parents were also thought to be interested in similar institutions located in other countries. One such institution in Denmark ${ }^{24}$ and one in Italy ${ }^{25}$ advertised in the Swedish press. In addition, several advertisements from travel companies arranging travel to Switzerland ${ }^{26}$ and Italy ${ }^{27}$ in the 1960 s announced that there were barnpensionat, alongside other amenities, at the marketed locations. Also, articles that brought up the issue of barnpensionat mentioned that there were several close to Copenhagen in Denmark, ${ }^{28}$ one in Bonn, Germany, ${ }^{29}$ and another in Paris, France. ${ }^{30}$ This data gives us reason to believe that barnpensionat were not a Swedishonly phenomenon. 
Services and Facilities

Services labeled as barnpensionat are diverse, with considerable difference in their organization, premises, and workforce, how many children they hosted, what services and facilities they offered, and when they were open. The lowest common denominator seems to be that barnpensionat offered full-board accommodation for children. We can conclude that scrutinizing newspaper material does not give us a complete or solid picture of their services or functions. When we try to calculate, for example, how many children could be simultaneously accommodated at individual barnpensionat, the advertisements present a very different picture from the news material. The advertisements often talk about the places as small and homelike, and when they state how many children can be accommodated there at any one time, the maximum number is fifteen. This contrasts with the news material, where ten children are put forward as the lowest number and between twenty and thirty children are common figures. Several barnpensionat are described in the news articles as having accommodation for up to fifty or fifty-five children. Such large numbers makes these establishments quite similar to the summer camps, which took many children at the same time.

In addition to descriptions and images printed in articles, a few ads provide images, which give further insights into the kinds of houses that were used as barnpensionat (Images 1 and 2). There are nice, spacious houses, often large country houses and villas, even castles. ${ }^{31}$ There are also a few city-center flats and some newly built properties constructed especially for this purpose. 


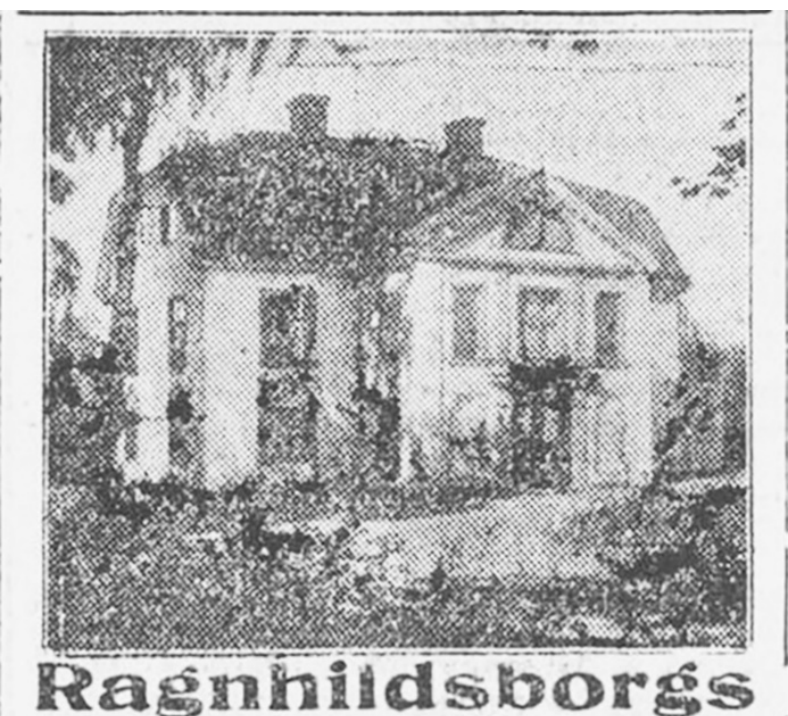

Barnpensionat rekommenderas. Kindergarten. Utbildad sköterska. Härlig natur. Tel. Södertälje 370 . B.

Image 1. Ad for Ragnhildsborgs barnpensionat. This is the first ad for a barnpensionat, with an inserted photograph. It shows the premises on which the institution is run. Svenska Dagbladet, January 2, 1928, 24.

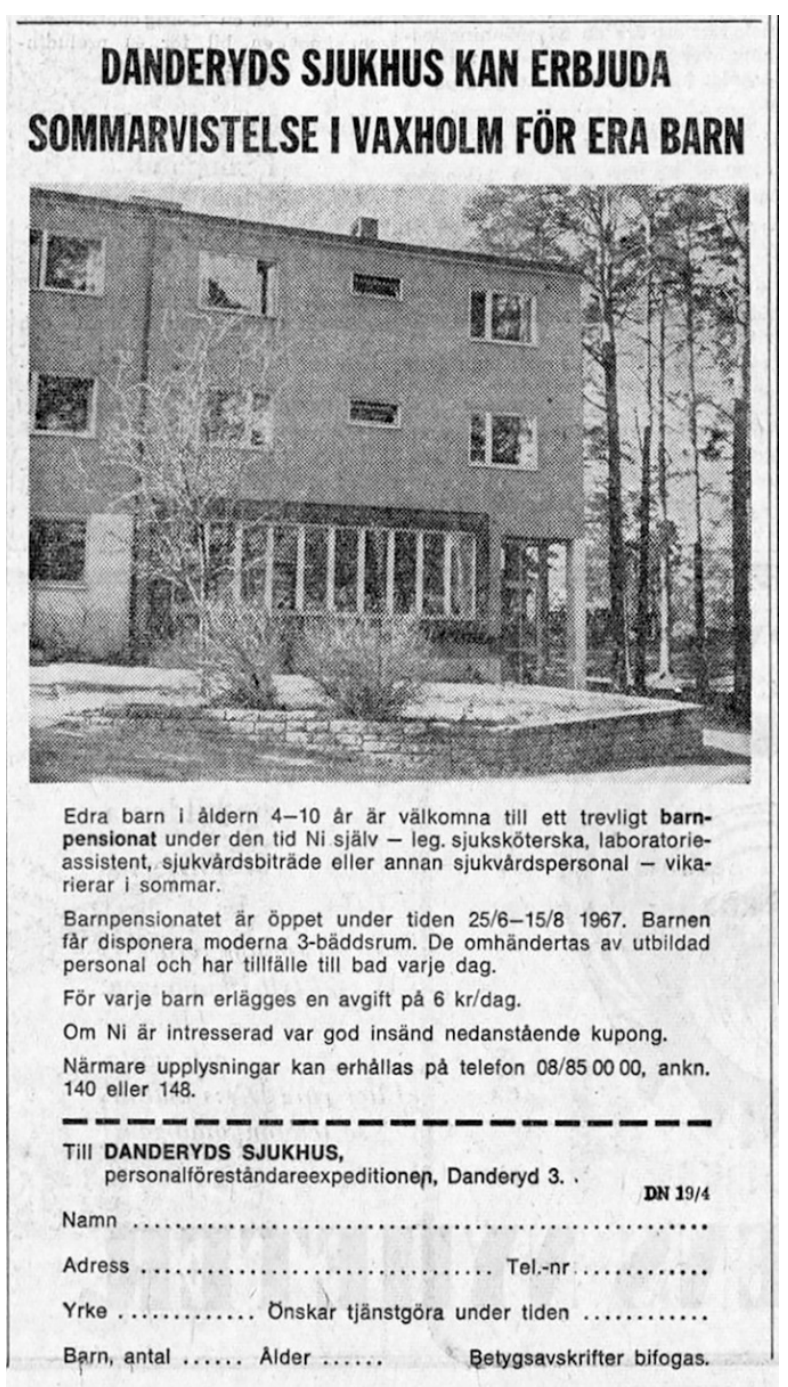


Image 2. Ad targeted at nurses who wish to work at a hospital during the summer and place their children in a barnpensionat. The image shows the premises, run by Stockholm county council. Dagens Nyheter, April 19, 1967, 17; Svenska Dagbladet, April 19, 1967, 10.

\section{Periods of Opening}

In an article published in 1924, Miss Ester Hill is said to have welcomed her 500th guest at Solvik barnpensionat, which she had run for 8.5 years. ${ }^{32}$ On average, this would mean that she had hosted about fifty-nine children a year. When these children were there, however, we do not know. They might all have been there at the same time, but their visits could have been spread out over the year. Some barnpensionat were open throughout the year, others only during school holidays and most only during the summer.

For all barnpensionat, summer seems to have been the main operating period. This might be explained by the fact that many parents had difficulties finding care for their children during the long summer holidays from school. Even when workers were granted vacation in 1938, their children's school holidays were still much longer, leaving parents with the problem of arranging care for their children. During the whole time period under study here, news articles and published letters to the editors deal with this topic. In particular, it was full-time working mothers who had these concerns.

Barnpensionat that were open throughout the year often state in their advertisements that they welcome children for both shorter and longer periods. The shortest time we find is at Lekstugan Barnabo in 1933, where children are said to be taken for periods ranging from one hour, a day, or a day and a night, up to a month at a time. ${ }^{33}$ In 1934, Fru Kåhres barnpensionat (Eng: "Mrs Kåhre’s barnpensionat") offered care by the day, week, month, and even year. ${ }^{34}$

Opening periods were in fact crucial for the categorization of barnpensionat and this, in turn, affected their regulatory framework. Before 1945, they were regulated by the hotel and guesthouse statute, which meant that these institutions were identified as hotels. However, with the 1945 amendment to the 1924 Child Welfare Act, barnpensionat were transferred to the child 
welfare sector. But the regulations differentiated between residential institutions that were open all year and those that only opened for limited periods. All-year institutions had to obtain permission from the authorities to run their businesses, but this was not required for temporarily open institutions. ${ }^{35}$ In an article published in 1950, we learn that barnpensionat that were open for a short period during the year were categorized as summer camps, which were not required to gain permission from the authorities - they only had to announce their existence. The same goes for private family homes that took in other people's children. As long as they were not hiring staff, gaining permission was not mandatory, nor did they have to undergo inspections by the authorities as those barnpensionat that were open all year did. ${ }^{36}$

In 1961, an article listed the seven all-year barnpensionat that were said to exist then. ${ }^{37}$ Only five years later, all of them had closed, according to another article. This article also mentions the much looser regulations for running a business as a summer camp. Still, there were some requirements: a physician had to be enrolled at the barnpensionat to check up on the children's health, the matron had to be familiar with children, and an approved system of fire protection had to be in place. ${ }^{38}$ The same year, 1966, the very last all-year barnpensionat was opened by the Salvation Army. ${ }^{39}$

\section{Services Offered}

Neither the advertisements nor the news material contain information about why individual parents hired the services offered by barnpensionat. However, a survey distributed to all identified residential childcare institutions in 1940 by the so-called Welfare Committee, established by the government to investigate the organization of Swedish welfare, does provide information of this kind. The Welfare Committee identified eight barnpensionat with a total of 320 children enrolled in 1940 . The results indicate that the most common reasons for these children to be sent to barnpensionat were for recreation in a healthy environment (76), that the child was prescribed a barnpensionat stay due to health or behavioral issues (51), and that the 
child's mother was sick or in need of rest (41). Other reasons mentioned were parents' travel (32), the mother's work (30), the mother's stay in a maternity hospital (11), and parental divorce (6) ${ }^{40}$ For as many as seventy-three children, the reason for their stay at the barnpensionat was reported as "other" or "unknown." Turning to a selection of the primary source- the archived surveys of two of the barnpensionat, containing information on fifty-six children-we conclude that different institutions could attract different clientele. "Solberga barnpensionat," located on the west coast, enrolled children for recreation — either for a summer holiday or due to a doctor's prescription. At the other institution, located in Stockholm, "Barnpensionat Fyrklövern," children were enrolled due to their parents' needs and commitments. For example, one fouryear-old boy was sent away for three weeks because his mother had not found a maid to hire. A seven-year-old girl, whose parents were actors touring in Finland, was sent to a barnpensionat in Sweden in order to escape the war. ${ }^{41}$ The fact that the survey was distributed in 1940, during the Second World War, may have impacted the reasons for enrollment, as the fate of the seven-year-old girl indicates.

The two kinds of arguments, one addressing parents' interests and the other addressing children's recreation, can also be supported through our analysis of advertisements. Sales pitches aimed at parents, specifically mothers, to leave their children at the barnpensionat centered around their needs when they were working, taking trips, sick, or were moving house. There are also a few advertisements suggesting that a child's stay at a barnpensionat was suitable when the mother was expecting and "when mother and father are having time off" in other words, when mother and father were intending to take time away from their children.

There are also advertisements that describe aspects of nature, in order to highlight their recreational suitability for children. Of the 122 advertising actors, forty-two mention nature, such as fresh air, woods, or lakes. It is obvious that nature was displayed as good and healthy for children. The same goes for playtime and leisure. Thirty-two out of the 122 barnpensionat 
advertisements mention leisure activities, such as outdoor bathing, playing, and sports of different kinds. Just as many claim that they offer good care or a good home for children. Eleven barnpensionat describe providing a good diet, and ten highlight the suitability of the house or the accommodation, such as being spacious, modern, or having nice beds. Only eight mention school, education, or theoretical learning, demonstrating that these were not summer schools or complements to regular school. Skills in spare-time sporting activities, such as gymnastics, horseback riding, or swimming were, however, taught in some places.

\section{Healthy Boys and Girls}

Different barnpensionat took in children of different ages. In the ads, the age ranges were not always explicitly mentioned, some actors changed the age range they were targeting over the years, and some mentioned age only when they advertised specifically for one or two children to fill their quota. Nevertheless, it is obvious from studying the advertisements that the most common age range was between two to three and seven years of age. Only twelve out of 122 actors welcomed children under the age of two years and very few welcomed children in their teens.

The children should be healthy. This was an explicit enrollment requirement in several advertisements: The children might be weak, but not ill. A few actors-for example, Syster Majas barnpensionat-explicitly mentioned that children with tuberculosis were not welcome. $^{43}$ 


\section{Trevligt sommarnöje för småflickor

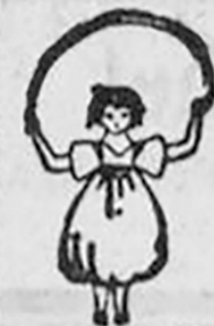 \\ m. lek, bad, eriluetsliv och små hushållsbestyr i Svensk- Franska Barnpensionen, Ek- hovs herrgård, Björnlunda, Södermanland, tel. Björnlun- da $45,1 \frac{1}{2}$ t. jvg fr. Sthlm. Lullu-Elisabeth Welander.}

Image 3. Ad for Svensk-Franska barnpensionen (Eng. "Swedish-French barnpensionat"). This is the only gender segregated barnpensionat, intended for little girls. Svenska Dagbladet, June 5, 1930, 28.

Only one barnpensionat, Svensk-Franska barnpensionen (Eng. "Swedish-French children's barnpensionat'), stated that it was gender segregated, with the argument that it was a nice place for little girls during the summer. There is going to be play, bathing, outdoor life, and small household tasks, the ad says. The gender-segregated orientation is underlined by a small drawn image of a girl wearing a dress and skipping rope (Image 3$).{ }^{44}$

\section{Actors Running Barnpensionat}

Unlike many daycare institutions (kindergartens, nurseries, etc.) operating as philanthropic/business hybrids - and which, from the 1940s onwards received state grantsbarnpensionat were excluded from such state economic support because they were offering full accommodation rather than childcare during daytime hours. Moreover, the cost of accommodating a child at a barnpensionat was higher than that at a children's home, probably because the accommodation was not subsidized by any state or municipal grant. This means that institutions labelled barnpensionat did not cross over from the private to the public sphere of welfare, as other childcare institutions succeeded in doing through state and municipal grants and a subsequent management takeover by the municipalities. ${ }^{45}$

Instead of being part of a state-subsidized welfare service, our results from analyzing commercial advertisements indicate that barnpensionat were private, predominantly female- 
run, for-profit businesses. With only a few exceptions, they were run by women. Sometimes these women employed hired staff and sometimes they ran the business themselves. Many were trained nurses, dry nurses or, later on, kindergarten teachers or the like. This is revealed by the advertisements, in which the titles of the matron and/or staff are often mentioned.

Some women found inspiration for their services abroad. In 1928, an article was published stating that Miss Lullu Welander, who ran Svensk-franska barnpensionatet among others, had studied the barnpensionat system in France. The same article argues that barnpensionat were very popular abroad. ${ }^{46}$ In 1954, Mrs. Ingrid Clementson, a former nurse on the ships connecting Europe with the United States, is said to have run a barnpensionat reminiscent of a "UN in miniature" due to its guests from many different countries. ${ }^{47}$

Fewer than ten of the 160 identified barnpensionat deviated from the character of being small, private, for-profit businesses. Exceptions to the privately run barnpensionat are represented, for example, by the condominium association HSB, which opened barnpensionat in newly built residential areas as part of their vison for modern housing in Stockholm in 1935. ${ }^{48}$ Industrial company ASEA in Västerås offered a barnpensionat for its employees. ${ }^{49}$ For ten years during the summer, between 1965 and 1975, several barnpensionat were also run by Stockholm county council. They were arrangements designed to solve a hospital crisis due to a severe lack of nurses and other personnel. These barnpensionat were opened in order to make it possible for housewives who used to work at the hospital to leave their children and return as staff during the summer when available staffing was short (Image 2). There were also a few NGOs, like the Salvation Army, operating barnpensionat, but these were very uncommon in this material.

\section{Conclusion}

In this study, we have outlined the for-profit care provision that co-existed alongside the expansion of public child welfare in Sweden. By studying barnpensionat through digitalized 
newspaper material, we have been able to present information about this service that was not possible to investigate before digitalization.

This article is able to conclude that, during the period between 1915 and 1975, at the very least, 160 barnpensionat operated across Sweden. Most of them were located relatively close to Stockholm. The largest number of such institutions was active during the 1950s. During that decade, a total of thirty-eight new actors advertised in the papers. The year 1951 marked a record, with ten new barnpensionat starting to advertise, and at least fourteen different ones were running at the same time.

According to the news material, barnpensionat offered full-board accommodation for up to a maximum of fifty-five children at one time. However, a smaller service with fewer children seems to have been preferable. Children were mainly hosted at barnpensionat during the summer, but some venues welcomed them at other times of the year. The length of stay that was offered varied from an hour up to a year. A few weeks, a month, or the summer holidays were typical time periods offered. Our results also suggest that, even though there were all-year barnpensionat, it was more manageable in terms of state regulations to run the service as a summer camp. The last all-year barnpensionat was opened in 1966 by the Salvation Army. As an NGO, this is a very unusual proprietor for a barnpensionat because they were primarily run by individual female entrepreneurs, often trained nurses.

The advertisements for barnpensionat were aimed at parents, especially mothers. They offered childcare when parents were working, traveling, sick or simply needed time off for some other reason. But these institutions were also promoted as recreational places where children could have fun and be well cared for in a healthy environment. Nature and physical activities such as outdoor bathing were frequently mentioned in the ads.

The children who were welcomed were healthy boys and girls, most often between the ages of two to three and seven years. Children enrolled at a barnpensionat were placed there 
by their parents or kin, not by the state, the municipality, or philanthropists intervening in the family. As such, the barnpensionat represent a service to the family that was external to the developing welfare state. Childcare around the clock was thus a commodity that was available on the market for the better part of the twentieth century.

Institutions labelled as barnpensionat vanished in the 1970s. The reasons for this are probably manifold, and it is beyond the scope of this article to draw any definite conclusions about why this happened. However, to stimulate future research, we would like to raise some queries. The Swedish welfare state's expansion of municipal childcare (daycare and leisuretime care) during the 1970 s and 1980s may have reduced the demand for barnpensionat services. Extended paid holidays for adults (four weeks was introduced in 1963, extended to five weeks in 1978) may also have eased the dilemma of providing childcare during the long school summer holidays. ${ }^{50}$ Is it possible that welfare measures targeting adults may have contributed to the decommodification of childcare? Or did this decommodification come about as a response to changing notions of parent-child separations, changing notions of the child's best interests and new parenting and family ideals?

\section{Notes}

\footnotetext{
${ }^{1}$ This figure excludes the residential care units for asylum-seeking children, which exploded in numbers after 2015, when many unaccompanied refugee minors arrived in Sweden. These institutions have been of temporary character and many of them are closing at the moment. See Tommy Lundström, Marie Sallnäs, and Emelie Shanks, "Stability and Change in the Field of Residential Care for Children: On Ownership Structure, Treatment Ideas and Institutional Logics," Nordic Social Work Research 10, 1 (2020), 43.

${ }^{2}$ Gøsta Esping-Andersen, The Three Worlds of Welfare Capitalism (Cambridge: Polity, 1990); Ruth Lister, Citizenship: Feminist Perspectives (London: Palgrave Macmillan, 1997); Diane Sainsbury, Gender, Equality, and Welfare States (Cambridge: Cambridge University Press, 1996).
} 
${ }^{3}$ Anne-Li Lindgren, and Ingrid Söderlind, Förskolans historia: förskolepolitik, barn och barndom (Malmö: Gleerups, 2019); Laura Hartman, ed., Konkurrensens konsekvenser: vad händer med svensk välfärd? (Stockholm: SNS förlag, 2011); Marie Sallnäs, and Stefan Wiklund, eds., Socialtjänstmarknaden: om marknadsorientering och konkurrensutsättning av individ- och familjeomsorgen (Stockholm: Liber, 2018); Magnus Linnarsson, Problemet med vinster: riksdagsdebatter om privat och offentlig drift under 400 år (Lund: Nordic Academic Press, 2017); Johannes Westberg, Funding the Rise of Mass Schooling: The Social, Economic and Cultural History of School Finance in Sweden, 1840-1900 (Cham: Palgrave Macmillan, 2017).

${ }^{4}$ Shurlee Swain, "What Price a Child? Commodification and Australian Adoption Practice 1850-1950," History of the Family 23, no. 1 (2018): 1-19.

${ }^{5}$ Astri Andresen, Hender små: bortsetting av barn i Norge 1900-1950 (Bergen: Fagbokforlaget, 2006); AnnKatrin Hatje, Från treklang till triangeldrama: barnträdgården som ett kvinnligt samhällsprojekt under 18801940-talen (Lund: Historiska media, 1999); David Kertzer, Sacrificed for Honor: Italian Infant Abandonment and the Politics of Reproductive Control (Boston: Beacon Press, 1993); Lydia Murdoch, Imagined Orphans: Poor Families, Child Welfare, and Contested Citizenship in London (New Brunswick: Rutgers University Press, 2006); Johanna Sköld, Fosterbarnsindustri eller människokärlek: barn, familjer och utackorderingsbyrån $i$ Stockholm 1890-1925 (Stockholm: Stockholms universitet, 2006); Shurlee Swain and Margot Hillel, Child, Nation, Race and Empire: Child Rescue Discourse, England, Canada and Australia, 1850-1915 (Manchester: Manchester University Press, 2010); Ingrid Söderlind, Barnhem för flickor: barn, familj och institutionsliv i Stockholm 1870-1920 (Linköping: Linköpings universitet, 1999).

${ }^{6}$ Museum Nordsjaelland, Pernilles Børnehotel i Rungsted, https://museumns.dk/lokalarkiver/hoersholmhistorier/skolehistorie-boern/pernilles-boernehotel

${ }^{7}$ Carina Gunnarsson, "Barnpensionat—en bortglömd barnomsorg: en studie av barnpensionaten i Dalarna mellan 1940 och 1970," Akka 2003, 71-104; Carin Dahlberg, "Barnpensionat en studie av en företeelse i det svenska folkhemmet under 1940- och 50-talen” (Stockholm: Institutet för folklivsforskning, Stockholms universitet, 1995).

${ }^{8}$ Lindgren and Söderlind, Förskolans historia, 9, 73.

${ }^{9}$ Shurlee Swain, History of Institutions Providing Out-of-Home Residential Care for Children (Sydney: Royal Commission into Institutional Responses to Child Sexual Abuse, 2014), 24-5. 
${ }^{10}$ Jenny Cronin, The Origins and Development of Scottish Convalescent Homes, 1860-1939 (Glasgow: Glasgow University, 2003), 103.

${ }^{11}$ Ann-Charlotte Münger, Stadens barn på landet: Stockholms sommarlovskolonier och den moderna välfärden (Linköping: Linköpings universitet, 2000); Ann-Charlotte Münger, Stockholms sommarkolonier under 130 år: en behovsprövad välfärdstjänst eller en fritidsverksamhet för alla? (Stockholm: Stockholmia, 2014), 276-7; Barbro Ljungdahl Zackrisson, Feriebarnets århundrade: Stockholmsbarn i ett landskap av ideal, rekreation och ekonomi 1900-2000 (Stockholm: Stockholmia, 2012).

${ }^{12}$ Joakim Landahl, Stad på låtsas: samhällssimulering och disciplinering vid Norra Latins sommarhem 1938_1965 (Göteborg: Daidalos, 2013).

${ }^{13}$ Laura Lee Downs, "Milieu Social or Milieu Familial? Theories and Practices of Childrearing among the Popular Classes in 20th-Century France and Britain: The Case of Evacuation (1939-45)," Family \& Community History 8, no. 1 (May 2005): 49-66.

${ }^{14}$ Aurora Lewén, ’Resfeber: berättelser från semesterns barndom 1938-1959," PhD Diss. Stockholm: Stockholms universitet, 2017, 102.

${ }^{15}$ Lewén, Resfeber, $136-7$.

${ }^{16}$ SOU 1938: 20; SOU 1942: 45; SOU 1943: 9; SOU 1944: 34; SOU 1955: 29.

${ }^{17}$ Svenska dagstidningar, https://www.kb.se/hitta-och-bestall/hitta-i-samlingarna/svenska-dagstidningar.html.

${ }^{18}$ Swain, "What Price a Child?," 3-4

${ }^{19}$ Tobias Karlsson, "Databasen Svenska dagstidningar—mycket text, mindre kontext," Historisk tidskrift 139, no. 2 (2019): 408-17.

${ }^{20}$ Because the database is still being processed, different time spans provide different coverage. The very old and the most recent newspapers are more fully represented than other periods. Since many newspapers published during the twentieth century are not yet included, this could had been an obstacle to this study. However, the largest Swedish daily newspapers—Aftonbladet, Dagens nyheter, Expressen, and Svenska Dagbladet—are fully digitalized. Searching for "barnpensionat" within these newspapers only, the hit curve is almost identical to that of the original search. Actually, the original search shows that more than two-thirds of the hits come from the fully digitalized newspapers Dagens nyheter and Svenska Dagbladet. From this, we can conclude that our material is quite representative for the time. However, both these newspapers, and thus our results, will have a special focus on Stockholm. In due time, it would be interesting to complete the study by including the not yet 
digitalized, mostly countryside local newspapers. When we returned to the database just over a year later (201912-13), repeating the search for "barnpensionat" there were 1,620 hits. That is forty-four more hits than in the original search. This is an effect of the ongoing digitalization, completing the database.

${ }^{21}$ Socialstyrelsen, Förekom övergrepp och kränkningar vid institutioner inom den sociala barnavården 1950-1980? (Stockholm: Socialstyrelsen 2006), 87-90.

${ }^{22}$ At the time of this research, newspapers such as Östgöta Correspondenten and Norrköpings tidningar, which are influential in the southeast part of Sweden, were not yet fully digitalized.

${ }^{23}$ Three barnpensionat announced in their advertisements that they would pick children up in Stockholm: Barnpensionat i Rättvik, later Bruntegårdens barnpensionat, Dagens Nyheter, May 27, 1956, 31; Barnpensionat Bohuslän, Dagens Nyheter, May 22, 1957, 37, and Barnpensionat i Jämtland, Svenska Dagbladet, February 5, $1960,19$.

${ }^{24}$ Svenska Dagbladet, May 17, 1959, 2; Dagens Nyheter, May 22, 1960, 47; Dagens Nyheter, May 7, 1961, 37.

${ }^{25}$ Svenska Dagbladet, July 23, 1961, 17.

${ }^{26}$ Svenska Dagbladet, May 28, 1960, 12; Svenska Dagbladet, October 31, 1969, 11.

${ }^{27}$ Svenska Dagbladet, May 2, 1967, 15; Svenska Dagbladet, May 10, 1967, 17.

${ }^{28}$ Dagens Nyheter, July 8, 1958, 10; Expressen, June 27, 1959, 10.

${ }^{29}$ Aftonbladet, August 1, 1960, 22.

${ }^{30}$ Hudiksvallstidningen, July 30, 1965, 9.

${ }^{31}$ Svenska Dagbladet, August 8, 1925, lördagsbilaga, 1.

${ }^{32}$ Dagens Nyheter, September 7, 1924, 1.

${ }^{33}$ Dagens Nyheter, January 11, 1933, 9.

${ }^{34}$ Svenska Dagbladet, September 20, 1934, 10.

${ }^{35}$ SOU 1944: 34. Socialvårdskommitténs betänkande. 9, Utredning och förslag angående revision av lagstiftningen om barnavårdsanstalter och fosterbarnsvård (Stockholm: 1944), 65, 122.

${ }^{36}$ Dagens Nyheter, February 5, 1950, 16.

${ }^{37}$ Expressen, March 23, 1961, 24.

${ }^{38}$ Expressen, June 19, 1966, Söndagsexpressen 16-7.

${ }^{39}$ The Salvation Army published the first ad for its newly opened barnpensionat in Svenska Dagbladet, August 20, 1966, 19. 
${ }^{40}$ SOU 1944: 34, 66 .

${ }^{41}$ Socialvårdskommittén YK 1185, vol. 88, Swedish National Archives.

${ }^{42}$ Sw.: "När Mor och Far ska ha ledigt inackorderar de med förtroende sina 'ungar' på Skälby barnpensionat." Dagens Nyheter, May 25, 1969, 18.

${ }^{43}$ Dagens Nyheter, April 11, 1915, 15.

${ }^{44}$ Svenska Dagbladet, June 5, 1930, 28.

${ }^{45}$ SOU 1943: 9, 20; SOU 1944: 34, 67; Lindgren and Söderlind, Förskolans historia, 61-7.

${ }^{46}$ Svenska Dagbladet, October 2, 1928, 9.

${ }^{47}$ Aftonbladet, March 16, 1954, 10.

${ }^{48}$ HSB markets its first barnpensionat in several ads in 1935. It is mentioned as a handy supplement to the facilities in its new apartments. See, for example, Dagens Nyheter, February 14, 1935.

${ }^{49}$ Articles mentioning that the company ASEA is building apartments in Västerås with access to a barnpensionat. Aftonbladet, November 19, 1941, 5; Dagens Nyheter, November 23, 1941, 11.

${ }^{50}$ Lindgren and Söderlind, Förskolans historia, 100. 